\title{
A Reason for Quantity Regulation
}

\section{Citation}

Glaeser, Edward L, and Andrei Shleifer. 2001. "A Reason for Quantity Regulation." American Economic Review 91 (2) (May): 431-435. doi:10.1257/aer.91.2.431.

\section{Published Version}

doi:10.1257/aer.91.2.431

\section{Permanent link}

http://nrs.harvard.edu/urn-3:HUL.InstRepos:33078975

\section{Terms of Use}

This article was downloaded from Harvard University's DASH repository, and is made available under the terms and conditions applicable to Other Posted Material, as set forth at http:// nrs.harvard.edu/urn-3:HUL.InstRepos:dash.current.terms-of-use\#LAA

\section{Share Your Story}

The Harvard community has made this article openly available.

Please share how this access benefits you. Submit a story.

Accessibility 


\title{
A Reason for Quantity Regulation
}

\author{
By Edward L. Glaeser And Andrei ShleIfER*
}

In a variety of situations, governments regulate undesirable activities by controlling quantities rather than charging taxes. Blue laws prohibit all liquor sales on Sundays rather than impose higher taxes on that day. Zoning restrictions limit commercial construction in residential areas rather than charge for nuisance to neighbors. Anti-smoking and anti-trust laws restrict rather than tax particular conduct. Fishing and hunting rules allow hunting during particular time periods rather than tax the catch. Pollution controls impose limits rather than tax emissions.

Quantity regulations are common in the financial sphere as well. In the United States, banking regulations for many years prohibited interstate banking, as well as ownership of investment banks by commercial banks. In many countries, commercial banks are limited in the amount of various activities they can pursue, such as real-estate investments or borrowing in foreign currency. In some countries, banking laws prohibit all lending to the parties related to the owners of the bank, the so-called related lending, rather than impose liability rules on loans to related parties that are found to be fraudulent or unsafe (Rafael La Porta et al., 2000).

Despite this common practice, economists generally prefer taxes (and liability rules) to quantity controls (and property-rights rules) (Robert Ellickson, 1973; Louis Kaplow and Steven Shavell, 1996, 1997; Nathaniel Keohane et al., 1998) as the instrument for reducing undesirable conduct. When explaining why quantity regulations are so pervasive, they first make the political-economy argument that quantity restrictions are favored by incumbent firms that wish to deter entry (James Buchanan and Gordon Tullock, 1975). But this argument is not general: it does not explain such quantity

\footnotetext{
* Department of Economics, Harvard University, Cambridge, MA 02138. We thank the National Science Foundation for financial support and Louis Kaplow for extremely helpful comments.
}

restrictions as blue laws and hunting and fishing regulations, which affect all market participants equally. Some academics also argue that, because certain activities, such as smoking, are seen as morally wrong by the community, their level is regulated at zero. In other instances, however, such as pollution and hunting, positive but limited levels of activity are allowed, inconsistent with the moral argument that the reason for quantity regulation is the special attraction of zero.

In this paper, we present an alternative reason for quantity regulations: one from the perspective of a benevolent government. We begin with the observation of Gary Becker and George Stigler (1974) that law enforcement is not free, but is fundamentally an economic problem. Throughout human history, and throughout the world today, there are chronic problems of under-enforcement (witness the low level of tax compliance in much of the developing world) and over-enforcement (by politically motivated prosecutors or regulators). An analysis of $\mathrm{Pi}$ gouvian taxes versus quantity restrictions must recognize that, in reality, neither policy is free and automatic to enforce.

In general, the choice of policies itself can facilitate or discourage enforcement, in two ways. First, policies can shape the incentives for enforcement. Second, policies can influence the costs of enforcement. In our earlier work (Glaeser and Sheifer, 2000; Glaeser et al., 2001), we have focused on incentives and shown that quantity regulations can be used as an optimal instrument to raise the rewards to law enforcers for identifying violations. Here we focus not on the incentives for the enforcers, but on the costs of finding violations: these costs are often lower in the case of quantity restrictions.

We show that, even when quantity regulations, unlike taxes, restrict some socially efficient conduct, the reduced costs of identifying violations can enhance enforcement and overall efficiency. Such reliance of quantity regulation is especially important when private enforcement is crucial, as in the case of enforcing 
zoning laws (by neighbors), anti-trust laws (by competitors), and hunting and fishing laws (by neighbors and competitors), among others. The optimality of quantity regulations on many occasions, of bright-line rules in the design of legal systems (Jonathan Hay et al., 1996), and of property rather than liability rules all emerge quite naturally once enforcement is treated as an economic problem.

A simple example of blue laws illustrates our point. Suppose that the government imposes an incremental tax on Sunday liquor sales. Such a tax, as compared to an outright prohibition, has the benefit of enabling people who value the ability to purchase liquor on Sundays to pay more. However, the tax is also subject to possible evasion, as vendors try to record Sunday liquor sales as occurring on Saturdays and otherwise "arbitrage" price differences (perhaps bribing tax collectors in the process). As a consequence, an inspector enforcing the tax rule has to expend considerable resources to find out whether proper taxes have been paid. This inspector may be discouraged from a thorough investigation, with the result that substantial Sunday liquor sales take place effectively untaxed. If, in contrast, there is a restriction against all liquor sales on Sundays, the detection and verification of violations is much cheaper: the inspector just needs to drive by the store. This effect is even more dramatic once we recognize that much of enforcement is done not by inspectors, but by citizens who complain to the police. Such private enforcement would be effectively eliminated if private citizens have to prove improper recording of sales. In contrast, any passerby can complain when he sees a liquor store operating on a Sunday. The reduction in the cost of enforcement can raise its overall amount enough to more than offset the efficiency losses from forgone Sunday liquor sales.

\section{A Model}

We focus on the case of some harmful conduct, such as pollution, but allow for some level of this conduct to be efficient. We compare a quantity limit on the level of pollution with a tax. In our model, the two rules are distinguished in terms of what needs to be discovered and verified to show a violation. In the case of a proven violation, the violator pays a fine.

We consider the problem of a law enforcer (either public or private), who derives a private benefit of $A$ from convicting a violator of a rule (the non-payer of a tax or the violator of a quantity restriction). This enforcer does not care whether the conduct is socially efficient; he only cares about busting polluters. We can think of a regulator whose career advances when he finds a violation (see James Q. Wilson, 1989; Glaeser et al., 2001), or a private enforcer such as an environmentalist who wishes to stop all pollution, a competitor trying to destroy competition, or a neighbor who aims to cancel construction in his view.

We assume that the violation of a quantity restriction is essentially free to find, but that it costs $c$ to prove (verify) in court. In contrast, the nonpayment of taxes costs $K$ to find as well as $c$ to prove in court. The assumption that tax nonpayments or underpayments are in some instances costly to identify is crucial to the model. It is motivated by our view that, with taxes, there are ample opportunities to hide or "arbitrage" production, such as Sunday liquor sales. In principle, the government can sell permits and licenses and demand that they be openly exhibited, as a way to enforce tax payments. However, it is difficult to design such licenses to tax each unit of harmful output; in fact, most licenses look more like quantity restrictions than like taxes. Moreover, inspectors can be bribed, and licenses fabricated. Perhaps most important for our argument, it is virtually impossible for private enforcers, such as neighbors or competitors, to know whether taxes have been paid, or whether production exceeds the licensed amount.

There are two kinds of firms potentially operating in the market: those with a private benefit of $B$ of producing and polluting (the share of these firms is $\pi$ ), and those with a private benefit of $b<B$. Each type generates the same amount of pollution. The social cost of this pollution is $t$, with $B>t>b$, so it is socially efficient for the first but not the second type of firm to operate. If either type of firm is shown in court to have violated a quantity restriction or to have failed to pay the tax, it pays a fine $Z$ after the fact. We assume that it is not efficient for 
both types to operate in the market as compared to the whole industry shutting down:

$$
W_{0}=\pi B+(1-\pi) b-t<0
$$

where $W_{0}$ is social welfare. In calculating welfare, we ignore the investigation and verification costs, as well as taxes and rewards to the enforcers, assuming that all of these are just transfers.

Consider the quantity restriction first. As a crude instrument, it does not distinguish between the two types of firms. Therefore, if $A>$ $c$, enforcers go after all polluters and fine them $Z$. In this case, since it is not efficient for both types to operate, $Z$ will be set high enough that neither type does, and the industry shuts down. In contrast, if $A<c$, the enforcers do not have strong enough incentives to go to court, and all firms operate and pollute with impunity. All that a quantity restriction can do in this model is to shut down the industry, provided that $A>c$.

Suppose alternatively that the government can impose a tax $t$ on pollution, equal to its social cost (this is the optimal tax in this model). In this case, each firm has two decisions to make: whether to produce/pollute and whether to pay the tax. If the firm does not pay the tax and is caught, it pays a penalty $Z$. We assume that the government does not stop production; it only exacts penalties. When $A<K+c$, there is no motivation for an enforcer to investigate whether the firm has paid its taxes, and no enforcement takes place. All firms operate, and social welfare is $W_{0}<0$.

The interesting case occurs when $A>K+$ $c$, so that the enforcer has some incentive to enforce. In this case, we have a mixed strategy equilibrium, in which some proportion $P$ of polluters pay the tax and a fraction $Q$ of enforcers investigate (if we had a distribution of $c$ 's and $B$ 's, we would have a pure strategy equilibrium). At the equilibrium $P$, enforcers are indifferent between investigating and not, which obtains when $(1-P) \times(A-c)+P \times 0=K$, or $P=(A-c-K) /(A-c)$.

In the mixed strategy equilibrium, all inefficient firms leave the market, while all efficient firms produce and pay taxes with probability $P$. The proportion of non-payers who are caught is equal to $Q$, the fraction of enforcers who inves- tigate. At the equilibrium $Q$, efficient firms are indifferent between paying taxes and cheating, which requires that $(1-Q) B+Q(B-Z)=$ $B-t$ or $Q=t / Z$. We can show that, at this level of investigation, all inefficient firms indeed prefer to leave the market rather than stay, pollute, and cheat (and we know that they never stay and pay the tax). The first-best solution is obtained in equilibrium, as the tax keeps exactly the efficient producers in the market. The level of social welfare is $\pi(B-t)>0$.

What is the optimal policy for the government? When $A>K+c$, and the incentives for enforcement of tax violations are sufficient, then the best policy here is a tax policy, which achieves the first-best resource allocation, though not complete tax compliance. In the region where $c<A<K+c$, tax enforcement is infeasible, but quantity enforcement is feasible. Such enforcement generates the level of social welfare equal to zero (since the industry shuts down), which is still higher than $W_{0}<0$ obtained when the whole industry operates. Finally, when $A<c$, neither the tax nor the quantity strategy is feasible to enforce, and the welfare level is $W_{0}<0$.

This simple framework captures nicely the enforcement difference between quantity controls and taxes (or property rights and liability rules). Taxes sometimes (though not always) yield the first-best solution, but failure to pay taxes might be expensive to detect, making the first-best solution impossible to achieve. Quantity controls are cheaper to enforce and can enable the government to provide some regulation when tax payments cannot be enforced. However, quantity controls are cruder and penalize some efficient conduct. (We see this also in the examples mentioned in the Introduction. Blue laws are cheaper to enforce than dayspecific liquor taxes but eliminate some efficient liquor sales. Prohibitions against related lending are cheaper to enforce than penalties but may prevent some of the best, and most informed, loans from banks to affiliated parties.) When verification of violations is sufficiently costly, even quantity controls are too expensive to enforce, and the only feasible policy is to leave the industry alone.

We briefly pause to consider a standard question in this literature: why would it not be 
efficient for the society, as an optimal incentive system, to adhere to the efficient tax rule, but to motivate enforcement by increasing $A$ or subsidizing $c$ and $K$ ? In many instances, of course, $A$ can be raised, as in the examples of triple damages or whistle-blower rewards, but one must recognize the limitations of this approach. In general, raising $A$ (or reducing $c$ and $K$ ) invites enforcers to bring illegitimate cases and increases the likelihood of false convictions. Indeed, one further argument for quantity regulations, developed by Glaeser and Shleifer (2000), is that such regulations make it easier for judges and superiors of an enforcer to verify his decisions, since judges and superiors themselves face verification costs that are lower in the case of bright-line rules. More generally, raising $A$ can run into feasibility limits. For these reasons, solutions involving raising $A$ or subsidizing $c$ and $K$ are not obviously desirable for motivating enforcement.

This analysis presents a reason for quantity regulations as a way to motivate law enforcement by reducing the cost of finding violations. We thus expect to see such quantity regulations in a variety of instances where accurate tax collection is prohibitively expensive. Blue laws, hunting and fishing restrictions where monitoring the catch is extremely costly, prohibitions of related lending, outright restrictions on certain kinds of pollution, zoning regulations, and other examples all nicely fit this story.

In this model, taxes are highly efficient and so are always preferred to quantity regulation when their collection can be enforced. More generally, quantity controls may be preferred even when collection can be enforced because taxation may provide inappropriate incentives for law enforcers. For example, when enforcers are paid for the revenues they collect, they may become overmotivated ( $A$ may be too high). Alternatively, quantity regulation might make it easier for the superiors to monitor the decisions of the enforcers themselves. In a more general framework, quantity regulation might be preferred to taxation even when both are enforceable.

\section{Extensions}

In the analysis thus far, we have not distinguished private and public enforcers. But our results are especially compelling for private enforcement. Private enforcers often have relatively low costs of verifying violations of quantity regulations but prohibitively high costs of detecting tax nonpayments. Thus zoning-law violations are almost always discovered by neighbors, who are disturbed by construction but for whom it might be impossible to verify whether the violator has paid the city for nuisance. Blue laws are enforced by concerned citizens, and fishing and hunting restrictions by competitors, neither of whom would have the knowledge of the payment of taxes or surcharges. Private enforcement, or at least private detection of violations, is ubiquitous in the world but would typically be infeasible without quantity regulations. It can even be argued that a government with weak enforcement capacity should simply produce quantity regulations and allow private parties to enforce them (Hay and Shleifer, 1998).

Our analysis has focused on the problem of regulation, but the use of quantities, or more generally bright-line rules, to control the behavior of agents in organizations is more pervasive. One area where this issue comes up is legal reform. In many legal systems, particularly those of civil-law countries, legality of conduct is described in terms of relatively simple brightline statutes, incorporated into legal codes. Such preference for bright-line rules as opposed to broader principles is best understood from the perspective of enforcement: bright-line rules make it cheaper for enforcers, both public and private, to verify violations, but also cheaper for their superiors to verify that enforcers are doing their job (Glaeser and Shleifer, 2000). Hay et al. (1996) recommend the use of bright-line rules in legal reforms in Russia precisely on the grounds of simplifying the verification of violations.

The use of quantity regulations to control agents in organizations is not specific to law enforcement. Many bureaucracies control employees through breaking their jobs into tasks and evaluating them based on the success in performing verifiable tasks (Wilson, 1989). The trade-off here is similar to that in tax versus quantity regulation. Task specification, like bright-line rules, may cause distortions in agent behavior and inefficiencies when the tasks are crudely defined; but tasks also make it cheaper 
to verify performance and may increase overall efficiency.

One limitation of quantity regulations is their crudeness, and the resulting incentive for rentseeking behavior aimed to get around them. When the Mexican government restricted its banks from borrowing abroad, the banks still borrowed, but through elaborate swap contracts with Western counterparties. Bright-line rules utilized by civillaw countries more generally often lead to similar problems. This limitation of quantity regulations is not, however, an argument in favor of taxation. The more elaborate tax and liability schemes in environments with poor enforcement can lead to still inferior outcomes.

In sum, we have described a reason for quantity regulation in an environment where enforcement costs are important, and we have pointed to some instances where the importance of these costs of enforcement swamps other determinants of optimal instrument choice.

\section{REFERENCES}

Becker, Gary and Stigler, George. "Law Enforcement, Malfeasance, and the Compensation of Enforcers." Journal of Legal Studies, January 1974, 3(1), pp. 1-18.

Buchanan, James and Tullock, Gordon. "Polluters' Profits and Political Response: Direct Control versus Taxes." American Economic Review, March 1975, 65(1), pp. 139-47.

Ellickson, Robert. "Alternatives to Zoning: Covenants, Nuisance Rules, and Fines as Land Use Controls." University of Chicago
Law Review, Summer 1973, 40(3), pp. 681-781.

Glaeser, Edward; Johnson, Simon and Shleifer, Andrei. "Coase versus the Coasians." Quarterly Journal of Economics, 2001 (forthcoming).

Glaeser, Edward and Shleifer, Andrei. "Legal Origins.” Mimeo, Harvard University, 2000.

Hay, Jonathan and Shleifer, Andrei. "Private Enforcement of Public Laws: A Theory of Legal Reform." American Economic Review, May 1998 (Papers and Proceedings), 88(2), pp. $398-403$.

Hay, Jonathan; Shleifer, Andrei and Vishny Robert. "Toward a Theory of Legal Reform." European Economic Review, April 1996, 40(3-5), pp. 559-67.

-Kaplow, Louis and Shavell, Steven. "Property Rules versus Liability Rules: An Economic Analysis." Harvard Law Review, February 1996, 109(4), pp. 713-90.

- "On the Superiority of Corrective Taxes to Quantity Regulation." National Bureau of Economic Research (Cambridge, MA) Working Paper No. 6251, 1997.

Keohane, Nathaniel; Revesz, Richard and Stavins, Robert. "The Choice of Regulatory Instruments in Environmental Policy." Harvard Environmental Law Review, Winter 1998, 22(2), pp. 313-67.

La Porta, Rafael; Lopez-de-Silanes, Florencio and Zamarripa, Guillermo. "Soft Lending and Hard Landing: Related Lending in Mexico." Mimeo, Harvard University, 2000.

Wilson, James Q. Bureaucracy. New York: Basic Books, 1989. 


\section{This article has been cited by:}

1. Nava Ashraf, Edward L. Glaeser, Giacomo A. M. Ponzetto. 2016. Infrastructure, Incentives, and Institutions. American Economic Review 106:5, 77-82. [Abstract] [View PDF article] [PDF with links]

2. LUIGI ZINGALES. 2015. Presidential Address: Does Finance Benefit Society?. The Journal of Finance 70:4, 1327. [CrossRef]

3. Jérôme Adda, Brendon McConnell, Imran Rasul. 2014. Crime and the Depenalization of Cannabis Possession: Evidence from a Policing Experiment. Journal of Political Economy 122, 1130-1202. [CrossRef]

4. Jeffrey Clemens. 2013. An Analysis of Economic Warfare. American Economic Review 103:3, 523-527. [Abstract] [View PDF article] [PDF with links]

5. Qiong Tian, Hai Yang, Hai-Jun Huang. 2011. Pareto efficient strategies for regulating public transit operations. Public Transport . [CrossRef]

6. Donghua Chen, Dequan Jiang, Shangkun Liang, Fangping Wang. 2011. Selective enforcement of regulation. China Journal of Accounting Research 4, 9-27. [CrossRef]

7. Mikael Priks. 2010. Competition among officials and the abuse of power. Public Choice . [CrossRef]

8. G DIVITA. 2008. Differences in pollution levels among civil law countries: A possible interpretation. Energy Policy 36, 3774-3786. [CrossRef]

9. Jacob Nussim, Avraham D. Tabbach. 2008. (Non)Regulable avoidance and the perils of punishment. European Journal of Law and Economics 25, 191-208. [CrossRef]

10. Iljoong Kim. 2008. Securities laws 'facilitating' private enforcement. European Journal of Law and Economics 25, 17-38. [CrossRef]

11. RAFAEL LA PORTA, FLORENCIO LOPEZ-DE-SILANES, ANDREI SHLEIFER. 2006. What Works in Securities Laws?. The Journal of Finance 61, 1-32. [CrossRef]

12. NICOLAS BOCCARD, XAVIER WAUTHY. 2006. QUALITY CHOICE, SALES RESTRICTION AND THE MODE OF COMPETITION. The Manchester School 74:10.1111/ manc.2006.74.issue-1, 64-84. [CrossRef]

13. Casey B. Mulligan, Andrei Shleifer. 2005. The Extent of the Market and the Supply of Regulation*. Quarterly Journal of Economics 120:10.1162/qjec.2005.120.issue-4, 1445-1473. [CrossRef]

14. Halanaik DiwakaraWater Markets in India: Economic and Institutional Aspects . [CrossRef]

15. Brian A. Jacob, Steven D. Levitt. 2003. Rotten Apples: An Investigation of The Prevalence and Predictors of Teacher Cheating*. Quarterly Journal of Economics 118:10.1162/qjec.2003.118.issue-3, 843-877. [CrossRef]

16. Edward L. Glaeser, Andrei Shleifer. 2003. The Rise of the Regulatory State. Journal of Economic Literature 41:2, 401-425. [Citation] [View PDF article] [PDF with links] 